\title{
Menilik Realitas Kebutuhan Pengguna Lulusan Teknologi Pendidikan Pada Bidang Jasa E-Learning di Indonesia
}

\author{
Briliana Firdaus*1, Shafira Aulia Darmawan $^{2}$, Raffie Ahmad Riesman Putra ${ }^{3}$, \\ Laksmi Dewi ${ }^{4}$ \\ brilianafirdaus@upi.edu ${ }^{1}$,shafiraaulia@upi.edu ${ }^{2}$,raffieahmad@upi.edu ${ }^{* 3}$, laksmidewi@upi.edu ${ }^{4}$ \\ 1,2,3,4 Teknologi Pendidikan, Fakultas Ilmu Pendidikan, Universitas Pendidikan Indonesia.
}

Received: Agustus 2021

Accepted: November 2021

Online Published: Desember 2021

\begin{abstract}
The Covid-19 pandemic has transformed conventional learning towards the use of e-Learning. Educational technology is a field of study that labels graduates with the main profile as developers of learning technology, one of which has competence in the sector of e-Learning. As a result, this study aims to look at the realities of the demands of educational technology graduates in the field of e-Learning services in Indonesia, both in terms of relevant institutions and based on the alumni job experience. The author conducts descriptive research using qualitative methods, including interviews with two samples of e-Learning service institutions in Indonesia (PT Menara Indonesia and PT Zeniora Edukasi Teknologi), as well as the distribution of open qualitative questionnaires to three alumni of Universitas Pendidikan Indonesia who are currently working in e-Learning service institutions. Work documents that support the research are also used to conduct documentation studies. The data was analyzed using various methods, including reduction and organization, as well as triangulation and re-checking with investigators. Based on the study's findings, it can be concluded that educational technology graduates are needed in e-Learning service institutions, both to receive graduates who fulfill the institution's criteria and the linearity of positions gained by educational technology alumni.
\end{abstract}

Keywords: Educational Technology, User Needs of Graduates, E-Learning Services

\begin{abstract}
Abstrak
Pandemi Covid-19 telah mentransformasikan pembelajaran konvensional ke arah pemanfaatan e-Learning. Adapun teknologi pendidikan merupakan bidang studi yang melabeli lulusannya dengan profil utama sebagai profesi pengembang teknologi pembelajaran, yang salah satunya memiliki kompetensi di bidang e-Learning. Maka dari itu riset ini bertujuan ini untuk menilik realitas kebutuhan pengguna lulusan teknologi pendidikan pada bidang jasa e-Learning di Indonesia, baik dari sisi lembaga yang relevan maupun berdasarkan pengalaman kerja alumni. Penulis menggunakan jenis riset deskriptif dengan metode kualitatif melalui wawancara terhadap dua sampel lembaga bidang jasa e-Learning di Indonesia (PT Menara Indonesia dan PT Zeniora Edukasi Teknologi), diseminasi kuesioner kualitatif terbuka kepada tiga alumni teknologi pendidikan Universitas Pendidikan Indonesia yang sedang bekerja di lembaga bidang jasa e-Learning, serta studi dokumentasi berdasarkan dokumen kerja yang mendukung. Data yang diperoleh dianalisis dengan serangkaian proses mulai dari reduksi, pengorganisasian, hingga pengecekan ulang dengan triangulasi investigator. Berdasarkan hasil penelitian dapat disimpulkan bahwa pada realitasnya lulusan teknologi pendidikan memang dibutuhkan pada lembaga bidang jasa e-Learning, baik itu dari posibilitas diterimanya lulusan berdasarkan kriteria yang diinginkan lembaga maupun linearitas pekerjaan yang diperoleh alumni teknologi pendidikan.
\end{abstract}

Kata kunci: Teknologi Pendidikan, Kebutuhan Pengguna Lulusan, Jasa E-Learning

\section{PENDAHULUAN}

Krisis Covid-19 memiliki andil besar dalam transformasi pada beragam sektor kehidupan di Indonesia, terutama pada bidang pendidikan. Lekas kasus perdana Covid-19 di 


\section{Educatio: Jurnal IImu Kependidikan}

Vol. 16, $\mathcal{N}$ o 2 Desember 2021, hal. 88-98

http://e-journal.hamzanwadi.ac.id/index.php/edc

e-ISSN: $2527-9998$

DOI: 10.29408/edc.v16i2.3964

Indonesia diumumkan pada tanggal 2 Maret (Aisyah et al., 2020), pemerintah dengan sigap memberhentikan segala kegiatan pendidikan tatap muka. Hal tersebut ditandai dengan terbitnya Surat Edaran Menteri Pendidikan dan Kebudayaan No. 4 Tahun 2020 tentang Pelaksanaan Kebijakan Pendidikan dalam Masa Darurat Penyebaran Corona Virus Disease (COVID-19), yang memperkenalkan kebijakan Belajar Dari Rumah (BDR). Dengan keluarnya edaran tersebut, maka proses belajar mengajar dilakukan melalui pembelajaran jarak jauh yang saat ini disebut dengan daring (dalam jaringan) (Irwandi, 2020). Sehingga dari itu meskipun mendadak dan tanpa persiapan yang matang, pendidik dituntut agar mempersiapkan dan memfasilitasi segala kebutuhan kegiatan belajar mengajar dari rumah tersebut.

Transformasi ruang pendidikan di atas membuat para guru beralih menggunakan platform daring, baik secara sinkronous maupun asinkronous. Pembelajaran dengan menggunakan daring membutuhkan internet sebagai kelancaran pembelajaran jarak jauh baik berupa video confrence yang memungkinkan terjadinya tatap muka atau dengan diskusi lain (Rohmadi, 2021). Dalam hal ini banyak ditemukan kegiatan pembelajaran secara asinkronus yang menggunakan platform LMS/Learning Management System (sistem manajemen pembelajaran). Entah itu dengan memanfaatkan yang sudah ada seperti Google Classroom (Kania et al., 2021), Schoology (Zulfiati et al., 2021), dan Moodle (Seprina \& Yulianingsih, 2021) ataupun mengembangkan sendiri seperti platform "FunMath" yang didesain oleh Sari dan Cahyono (2020). Selain itu menurut riset Subkhan et al. (2021), diketahui bahwa LMS juga dimanfaatkan dalam pembelajaran bauran dengan cara mengintegrasikan aplikasi konferensi virtual ke dalamnya. Meningkatnya penggunaan LMS dalam pembelajaran daring mengubah stigma e-Learning dari yang hanya pelengkap menjadi sebuah solusi dan tren kebutuhan pembelajaran saat pandemi.

Di sisi lain kini industri pun membutuhkan e-Learning sebagai media untuk mewujudkan model proses pembelajaran yang menguraikan tujuan perusahaan (Emmanuel \& Kusumawardani, 2020). Kondisi e-Learning pada dunia industri pun selaras dengan kondisinya pada pendidikan formal. Lembaga penyedia jasa e-Learning di Indonesia pun mengalami peningkatan pesat sebagai solusi kebutuhan pendidikan dan pelatihan saat pandemi. Bahkan menurut laporan riset Adkins (2016), Indonesia menempati peringkat ke-17 pada tahun 2016 di pasar global e-Learning dan telah diperkirakan meningkat $25 \%$ setiap tahunnya menjadi peringkat ke-8 pada tahun 2021. Peningkatan ini tentunya menjadi peluang terbukanya lapangan kerja di industri bidang jasa e-Learning. Lapangan kerja bidang tersebut umumnya membutuhkan modal insani berupa tenaga kerja yang cakap dan ulung dalam aspek desain dan pengelolaan instruksional serta dibekali literasi IPTEK (ilmu pengetahuan dan teknologi) (Prawiradilaga, 2016).

Adapun bidang studi yang memiliki relevansi kompetensi dengan kebutuhan kerja di lembaga bidang jasa e-Learning adalah teknologi pendidikan. Teknologi pendidikan mampu mengintegrasikan teknis teknologi dengan pedagogi ke dalam proses bisnis e-Learning, yang 


\section{Educatio: Jurnal IImu Kependidikan}

Vol. 16, No 2 Desember 2021, hal. 88-98

http://e-journal.hamzanwadi.ac.id/index.php/edc

e-ISSN: 2527-9998

DOI: 10.29408/edc.v16i2.3964

menjadi dasar kesuksesan revolusi e-Learning tahun ke tahun (Huang et al., 2019). Ini berarti lulusan teknologi pendidikan bisa diandalkan oleh para stakeholders ataupun pengguna lulusan di bidang jasa e-Learning.

Pernyataan di atas diperkuat dengan standar teknolog pendidikan di Indonesia, yang disebut sebagai Pengembang Teknologi Pembelajaran (PTP), diatur dalam Peraturan Menteri PAN-RB Nomor 28 Tahun 2017. Jabatan fungsional PTP ditugaskan berbagai pekerjaan yang menunjukkan multi-keahlian, mulai dari analis, desainer, produser, teknisi, pengendali, serta evaluator sistem, model, dan media teknologi pembelajaran. Kehadiran standar tersebut mengharuskan lembaga penyelenggara pendidikan formal mendesain kompetensi lulusan yang mampu mencapai tugas - tugas jabatan fungsional PTP. Dengan kata lain lulusan teknologi pendidikan sudah dibekali kompetensi sebelum terjun ke bidang jasa e-Learning, yakni fusi antara teknis teknologi dengan pedagogi yang secara tersirat bisa dilihat pada tugas jabatan fungsional PTP.

Selain kondisi de jure di atas, jika mengambil sampel teknologi pendidikan di Universitas Pendidikan Indonesia dapat diketahui bahwa kompetensi lulusan teknologi pendidikan tidak sebatas lingkup jabatan fungsional PTP saja. Profil lulusan utama memang sebagai pengembang teknologi pendidikan, namun juga dilengkapi profil lulusan penunjang sebagai pengembang kurikulum, wirausahawan bidang teknologi pendidikan, serta pengajar (Dewi, 2020). Sehingga bisa dikatakan spektrum kompetensi teknologi pendidikan yang bisa dimanfaatkan dalam menjalankan proses bisnis e-Learning di Indonesia sangat luas.

Riset seputar profesi teknologi pendidikan sudah pernah dilakukan oleh para peneliti sebelumnya. Namun pada umumnya pembahasan masih stagnan di jabatan fungsional pengembang teknologi pembelajaran seperti analisis peran dan tantangan (Warsita, 2017), pengembangan kapasitas dan kualitas (Susilawati, 2015), serta peluang dan tantangan produksi profesi (Warsita, 2020). Selain itu pun bahasannya masih secara umum seperti pembahasan peluang profesi berdasarkan kompetensi AECT (Ariani, 2017). Belum ada yang secara spesifik membahas profesi teknologi pendidikan yang menjurus pada bidang keahlian tertentu.

Berdasarkan uraian di atas, kompetensi lulusan teknologi pendidikan diperkirakan sangat menunjang mereka jika nantinya akan bekerja di bidang jasa $e$-Learning. Maka dari itu penulis tertarik untuk menilik lebih dalam realitas sesungguhnya terkait kebutuhan pengguna lulusan teknologi pendidikan pada bidang jasa e-Learning di Indonesia melalui riset ini. Dengan lingkup lulusan teknologi pendidikan dari Universitas Pendidikan Indonesia, penulis memfokuskan pokok bahasan ke dalam dua pertanyaan: 1) Bagaimana realitas kebutuhan akan lulusan teknologi pendidikan bagi lembaga bidang jasa e-Learning di Indonesia? dan 2) Bagaimana realitas kebutuhan pengguna lulusan teknologi pendidikan berdasarkan pengalaman kerja lulusan teknologi pendidikan di bidang jasa $e$-Learning?.

Adapun signifikansi riset ini secara teoretis diharapkan dapat menjadi tambahan wawasan bagi pembaca terkait kondisi realitas lulusan teknologi pendidikan di Indonesia, 
terkhusus pada bidang jasa e-Learning. Sedangkan untuk signifikansi dari sisi kepraktisan diharapkan bisa menjadi bahan evaluasi studi penelusuran lulusan dan riset mengenai kebutuhan pengembangan kompetensi bagi lulusan teknologi pendidikan, atau bidang studi lainnya yang relevan, demi menyelaraskan kebutuhan kerja pada bidang jasa $e$-Learning.

\section{METODE PENELITIAN}

Penulis menggunakan jenis penelitian deskriptif yang sesuai dengan perspektif Ali (2014) dalam ranah penelitian perilaku dan sosial. Adapun metode penelitian yang digunakan penulis adalah kualitatif sebagai turunan dari penelitian deskriptif (Ali, 2014). Yang mana penelitian dengan metode tersebut bertujuan untuk mendeskripsikan realitas kebutuhan pengguna lulusan teknologi pendidikan pada bidang jasa E-Learning di Indonesia. Untuk memperoleh data kualitatif, penulis menggunakan teknik pengumpulan data primer (langsung diperoleh dari sampel dengan cara wawancara dan mendiseminasikan kuesioner kualitatif terbuka) maupun sekunder (diperoleh melalui dokumen yang mendukung studi dokumentasi) (Sugiyono, 2019).

Penulis mengambil sampel penelitian berupa lembaga penyedia jasa e-Learning yang bermitra dengan teknologi pendidikan Universitas Pendidikan Indonesia, yaitu PT Menara Indonesia (wawancara tanggal 16 Agustus 2021 dengan Ichsan Mochtar) dan PT Zeniora Edukasi Teknologi (wawancara tanggal 18 Agustus 2021 dengan Qonita Hijrina Lillah). Sedangkan untuk sampel lulusan teknologi pendidikan Universitas Pendidikan Indonesia diambil tiga alumni yang sudah bekerja di bidang jasa e-Learning dari angkatan yang berbeda, yaitu: Lingga Yuni Purwaka dari Ruangguru dan YPBB (Angkatan 2014), Aldy Hermawan dari Odigia Curriculum Developer (Angkatan 2016), dan Rahma Nur Karimah dari CoLearn (Angkatan 2017).

Sumber data primer penelitian ini merupakan data hasil wawancara kepada sampel lembaga penyedia jasa $e$-Learning di Indonesia yang bisa dilihat kisi - kisi instrumennya pada Tabel 1.

Tabel 1. Kisi - Kisi Instrumen Wawancara Lembaga

\begin{tabular}{ll}
\hline \multicolumn{1}{c}{ Dimensi } & \multicolumn{1}{c}{ Komponen } \\
\hline Profil Lembaga & 1. Latar belakang lembaga \\
& 2. Aktivitas e-Learning lembaga \\
Struktur Organisasi & 1. Relevansi jabatan yang ada dengan kompetensi teknologi \\
& $\begin{array}{l}\text { 2. Kendidikan } \\
\text { Kondisi lulusan }\end{array}$ \\
\hline
\end{tabular}

Sumber data primer selanjutnya adalah diseminasi kuesioner kualitatif terbuka kepada sampel alumni teknologi Pendidikan Universitas Pendidikan Indonesia yang bekerja di lembaga penyedia jasa e-learning, bisa dilihat kisi - kisi instrumennya pada Tabel 2. 


\section{Educatio: Jurnal IImu Kependidikan}

Vol. 16, $\mathcal{N}$ o 2 Desember 2021, hal. 88-98

http://e-journal.hamzanwadi.ac.id/index.php/edc

e-ISSN: 2527-9998

DOI: 10.29408/edc.v16i2.3964

Sedangkan sumber data sekundernya diperoleh melalui studi dokumen berdasarkan publikasi ilmiah dan dokumen pemerintah maupun akademik, yang mendukung dan relevan dengan topik mengenai kebutuhan Teknologi Pendidikan yang berkaitan dengan $e$-Learning.

Tabel 2. Kisi - Kisi Instrumen Kuesioner Alumni

\begin{tabular}{ll}
\hline \multicolumn{1}{c}{ Dimensi } & \multicolumn{1}{c}{ Komponen } \\
\hline Pekerjaan & 1. Tempat dan divisi pekerjaan \\
Kompetensi & 2. Tugas pokok pekerjaan \\
& 1. Linearitas pekerjaan dengan teknologi pendidikan \\
\hline
\end{tabular}

Untuk sumber data sekunder yang diperoleh berdasarkan studi dokumentasi, penulis meminta izin untuk menganalisis dokumen pekerjaan yang relevan dengan bidang teknologi pendidikan dari masing-masing sampel.

Penulis memerlukan pemaknaan data yang berasal dari sumber penelitian sehingga dilakukan analisis data kualitatif. Proses analisis data secara bertahap dimulai dari reduksi data, mengorganisasi data, sampai memverifikasi data (Ali, 2014). Reduksi dilakukan dengan cara memilah sumber data yang diperoleh agar terfokus dengan tujuan sehingga mengandung informasi yang padat terkait realitas kebutuhan akan lulusan teknologi pendidikan, baik bagi lembaga maupun berdasarkan pengalaman kerja lulusan yang bekerja pada bidang jasa $e$ Learning di Indonesia. Kemudian penulis mengorganisasi data dengan menata draf informasi secara deskriptif. Ketika sudah rampung, draf tersebut akan melalui tahap verifikasi data dengan cara triangulasi investigator. Tiap sampel bergerak dengan fokus latar belakang yang berbeda meskipun dinaungi oleh pekerjaan di bidang jasa e-Learning, sehingga memungkinkan pengecekkan kembali informasi melalui triangulasi investigator yang pada dasarnya mengakomodasi berbagai kekhasan yang dimiliki oleh sampel dalam satu naungan yang sama (Ali, 2014).

\section{HASIL PENELITIAN}

\section{Realitas Kebutuhan Akan Lulusan Teknologi Pendidikan Bagi Lembaga Bidang Jasa $e$ - Learning di Indonesia}

\section{M-Knows Consulting / PT Menara Indonesia}

PT Menara Indonesia yang dikenal dengan nama M-Knows Consulting bergerak sebagai konsultan manajemen dengan klien yang mayoritasnya dari perusahaan swasta. Kegiatan yang mereka tawarkan dengan klien tersebut bentuknya berupa pelatihan. Ada dua jenis pelatihan yang ditawarkan oleh M-Knows Consulting yaitu: 1) Public Training, merupakan pelatihan dengan sifat terbuka yang bisa diisi dari berbagai perusahaan sekaligus. Topik dan temanya ditentukan langsung dan ditawarkan oleh M-Knows Consulting ke publik, dan 2) In-House Training, merupakan pelatihan eksklusif yang diselenggarakan dan didesain 


\section{Educatio: Jurnal IImu Kependidikan}

Vol. 16, No 2 Desember 2021, hal. 88-98 http://e-journal.hamzanwadi.ac.id/index.php/edc

e-ISSN: $2527-9998$ DOI: 10.29408/edc.v16i2.3964

atas permintaan dan kebutuhan klien. Kedua pelatihan tersebut dilaksanakan secara daring karena kondisi pandemi. Oleh karenanya M-Knows Consulting sangat bergantung kepada penggunaan LMS sebagai media e-Learning dalam pelatihan.

Platform e-Learning yang dimanfaatkan oleh M-Knows Consulting umumnya berasal dari pihak ketiga yang sudah dipakai oleh klien. Namun demikian M-Knows Consulting juga bekerja sama dengan vendor eksternal untuk mengembangkan e-Learning, baik platform maupun kontennya yang sesuai dengan kebutuhan klien. Selain itu M-Knows Consulting juga sedang mengembangkan platform e-Learning sendiri dalam proyek "Kampus Gratis" pada program Magang Bersertifikat Kemenbudristek 2021. Adapun posisi yang secara gamblang menunjukkan bahwa pekerjaannya menerima mahasiswa dengan jurusan teknologi pendidikan adalah: Lecturer Management and Learner Progress Tracking, Instructional Designer, dan Pengembang konten video dan presentasi pembelajaran. Namun tidak menutup kemungkinan untuk posisi lain.

Sebagai bagian dari pelatihan, M-Knows Consulting juga melakukan jasa assessment for technical competence. Mereka akan bertindak sebagai asesor kompetensi dengan model asesmen yang disesuaikan dengan kebutuhan pelatihan dan klien. Sehingga ada kemungkinan lulusan teknologi pendidikan tidak terbatas bekerja sebagai pengembang e-Learning saja melainkan juga sebagai asesor atau evaluator kompetensi dan program pelatihan.

Kriteria yang dapat bekerja di M-Knows Consulting adalah seseorang dengan latar belakang lulusan pendidikan, sumber daya manusia, manajemen, dan psikologi. Namun tidak menutup kemungkinan bagi jurusan lainnya. Hal ini dapat dipertimbangkan tergantung saat proses rekrutmen. Misalnya jika pelamar memiliki pengalaman dan minat yang relevan serta banyak bergabung dengan kegiatan kemahasiswaaan. M-Knows Consulting akan banyak berhubungan dengan klien sehingga orang dengan kemampuan adaptasi dan sosialisasi yang tinggi dapat dipertimbangkan. Begitu juga dari sisi teknologi, dalam beberapa tahun terakhir perusahaan M-Knows Consulting membutuhkan SDM yang mahir dalam bidang IPTEK sebagai pengembang LMS mereka. Lulusan program studi Teknologi Pendidikan pun sangat berpeluang untuk bekerja di M-Knows Consulting karena sebelumnya mereka banyak menerima atau merekrut lulusan Teknologi Pendidikan.

\section{Zeniora Education / PT Zeniora Edukasi Teknologi}

Zeniora Education merupakan nama lain dari PT Zeniora Edukasi Teknologi, sebuah perusahaan rintisan bidang teknologi pendidikan yang berfokus memfasilitasi siswa SMA/lulusan SMA yang berupaya agar lulus seleksi ujian masuk perguruan tinggi (khususnya negeri) melalui bank soal dan try out yang dimiliki Zeniora Education. Fasilitas tersebut diwujudkan dalam bentuk mobile application learning dan web-based learning sehingga mudah diakses di manapun pengguna berada. Keseluruhan tampilan e-Learning Zeniora Education dibuat secara mandiri sehingga tidak rigid. 


\section{Educatio: Jurnal IImu Kependidikan}

Vol. 16, $\mathcal{N}$ o 2 Desember 2021, hal. 88-98 http://e-journal.hamzanwadi.ac.id/index.php/edc

e-ISSN: 2527-9998 DOI: 10.29408/edc.v16i2.3964

Adapun untuk bekerja di Zeniora Education tidak mementingkan program studi pelamar melainkan pengalaman dan kompetensi yang dimiliki. Kecuali untuk bidang yang membutuhkan keterampilan teknologi informasi seperti Back-end dan Front-end biasanya dicari yang memang relevan dengan kompetensi program studi tertentu. Zeniora Education lebih mementingkan apakah pelamar sesuai dengan nilai dan budaya kerjanya, yaitu menjunjung tinggi nilai keluarga, kesehatan, kepercayaan dan integritas, sahabat, dan pekerjaan.

Kondisi ini menunjukkan bahwa lulusan teknologi pendidikan sangat mungkin diterima di Zeniora Education karena bukan hanya terdapat kesempatan sebagai pengembang e-Learning, melainkan pengembang usaha teknologi pendidikan secara keseluruhan. Untuk yang sangat erat kaitannya dengan teknologi pendidikan sendiri ada pada divisi Analyst and Administration yang bertugas menganalisis kinerja pegawai melalui perancangan model asesmen sebaya dan atasan, serta Learning and Development yang mendesain program pengembangan kompetensi mulai dari menganalisis kebutuhan, menyelenggarakan, hingga mengevaluasi dan mengecek apakah program yang dilaksanakan berdampak atau tidak. Sayangnya saat ini hanya terdapat pekerja dari teknologi pendidikan sebagai User-Content Testing yang bertugas sebagai penjamin mutu soal dan tampilannya pada e-Learning Zeniora Education.

\section{Realitas Kebutuhan Pengguna Lulusan Teknologi Pendidikan Berdasarkan Pengalaman Kerja Lulusan Teknologi Pendidikan UPI di Bidang Jasa e-Learning}

Penulis telah mendiseminasikan kuesioner kepada tiga lulusan teknologi pendidikan di UPI dari angkatan yang berbeda (2014, 2016, dan 2017) dan sedang bekerja di lembaga bidang jasa e-Learning yang berbeda di Indonesia. Hasilnya yakni:

Rahma Nur Karimah dari angkatan 2017 yang bekerja di CoLearn, menempati divisi Audiovisual Quality Control yang mempunyai tugas yaitu mereviu video pembelajaran yang dibuat oleh tutor dari aspek audio dan visualnya yang akan dimasukkan ke dalam e-Learning CoLearn.

Aldy Hermawan dari angkatan 2016 yang bekerja di Odigia Curriculum Developer, spesialis diklat di bidang pengembangan kurikulum. Beliau bekerja di bagian Commercial Training yang mempunyai spesifikasi tugas yaitu mengelola pelatihan-pelatihan yang diadakan Odigia mulai dari perencanaan sampai evaluasi. Adapun tugas tambahan yang dikerjaan oleh beliau adalah mendesain dan mengedit video untuk berbagai keperluan.

Lingga Yuni Purwaka dari angkatan 2014 bekerja di Ruang Guru yang notabenenya merupakan start-up teknologi pendidikan yang mendekati level unicorn. Beliau bekerja di bagian Curriculum Designer yang mempunyai spesifikasi tugas pemetaan kelas, membuat outline capaian, juga menjamin mutu hasil pekerjaan kreator konten.

Di dalam melakukan pekerjan, tentunya terdapat permasalahan yang dihadapi. Menurut Rahma permasalahan yang dihadapi pada saat melakukan pekerjaan adalah 
mengenai adaptasi pada saat baru memulai bekerja di tempat bekerja yang sekarang beliau jalani. Karena pekerjaan yang dijalani berbeda, Aldy memiliki permasalahan yang berbeda pula dengan Rahma. Beliau merasa memiliki kesulitan ketika menghadapi mengenai Copywriting. Sementara untuk Lingga abstain.

\section{PEMBAHASAN PENELITIAN}

\section{Realitas Kebutuhan Akan Lulusan Teknologi Pendidikan Bagi Lembaga Bidang Jasa $e$ - Learning di Indonesia}

\section{M-Knows Consulting / PT Menara Indonesia}

Berdasarkan hasil penelitian, lulusan Teknologi Pendidikan dibutuhkan untuk bekerja pada M-Knows Consulting sebagai lembaga bidang jasa e-Learning. Hal ini karena pada program Magang Merdeka Bersertifikat 2021, mereka sedang mengembangkan platform $e$ Learning dalam proyek "Kampus Gratis". Pada lowongan program tersebut, perusahaan MKnows Consulting menyebutkan dengan jelas bahwa mahasiswa dengan jurusan teknologi pendidikan dapat mengisi beberapa posisi yang tersedia, yakni: Lecturer Management and Learner Progress Tracking, Instructional Designer, dan Pengembang konten video dan presentasi pembelajaran.

Lalu M-Knows Consulting juga melakukan jasa assessment for technical competence. Sehingga ada kemungkinan lulusan teknologi pendidikan tidak terbatas bekerja sebagai pengembang e-Learning saja melainkan juga sebagai asesor atau evaluator kompetensi dan program pelatihan.

Lulusan teknologi pendidikan pun memenuhi kriteria yang disebutkan pihak MKnows Consulting. Salah satunya dari latar belakang di bidang pendidikan. Kemudian lulusan teknologi pendidikan juga sudah dibekali oleh mata kuliah yang mengakomodasi kompetensi di bidang manajemen, personalia, serta psikologi dengan dasar ilmu kependidikan. Kemahiran dalam bidang IPTEK yang dibutuhkan perusahaan juga dimiliki oleh para lulusan teknologi pendidikan karena mampu menguasai keilmuan e-Learning sehingga berpeluang bekerja sebagai pengembang LMS di M-Knows Consulting.

\section{Zeniora Education / PT Zeniora Edukasi Teknologi}

Zeniora Education lebih mementingkan apakah pelamar sesuai dengan nilai dan budaya kerjanya, yaitu menjunjung tinggi nilai keluarga, kesehatan, kepercayaan dan integritas, sahabat, dan pekerjaan.

Kondisi ini menunjukkan bahwa lulusan teknologi pendidikan sangat mungkin diterima di Zeniora Education karena bukan hanya terdapat kesempatan sebagai pengembang e-Learning secara komprehensif, melainkan pengembang usaha teknologi pendidikan secara keseluruhan. Untuk yang sangat erat kaitannya dengan teknologi pendidikan sendiri ada pada divisi Analyst and Administration, Learning and Development, dan User-Content Testing. 


\section{Educatio: Jurnal IImu Kependidikan}

Vol. 16, $\mathcal{N}$ o 2 Desember 2021, hal. 88-98 http://e-journal.hamzanwadi.ac.id/index.php/edc

e-ISSN: $2527-9998$ DOI: 10.29408/edc.v16i2.3964

\section{Realitas Kebutuhan Pengguna Lulusan Teknologi Pendidikan Berdasarkan Pengalaman Kerja Lulusan Teknologi Pendidikan UPI di Bidang Jasa e-Learning}

Lulusan Program Studi Teknologi Pendidikan Universitas Pendidikan Indonesia diberikan gelar akademik S.Pd. atau Sarjana Pendidikan. Profil lulusan Teknologi Pendidikan UPI adalah sebagai: 1) pengembang teknologi pendidikan (Perancang, pengembang, pengelola, pengevaluasi dan peneliti teknologi pendidikan dan pembelajaran, baik yang berbasis TIK ataupun non-TIK), 2) pengembang kurikulum (Perancang, perekayasa, pengelola, pengevaluasi dan peneliti kurikulum), 3) wirausahawan bidang teknologi pendidikan (Perancang, Pengelola, Penghasil produk dan jasa dan Pemasar dalam bidang Teknologi Pendidikan), dan 4) pengajar (terkhusus bidang keilmuan yang linear dengan: Teknologi Pendidikan, Kurikulum dan Pembelajaran, Teknologi Informasi dan Komunikasi, serta Multimedia) (Dewi, 2020). Keseluruhan profil lulusan tersebut bersifat fleksibel, dalam artian mampu berkarier di setiap jalur, jenis, dan jenjang pendidikan.

Informasi profil lulusan teknologi pendidikan di atas menjadi tolok ukur antara linearitas kompetensi lulusan dengan pekerjaannya. Adapun ketiga sampel yang menjawab kuesioner sudah memenuhi linearitas yang dimaksud. Pada ranah pengembang teknologi pembelajaran, pekerjaan Audiovisual Quality Control yang diemban Rahma Nur Karimah di CoLearn termasuk ke dalamnya. Sedangkan pada ranah pengembang kurikulum, terdapat pekerjaan Aldy Hermawan sebagai Commercial Training Staff di Odigia Curriculum Developer serta Curriculum Designer yang ditekuni oleh Lingga Yuni Purwaka di Ruangguru. Linearitas pekerjaan dengan profil lulusan yang diharapkan oleh program studi teknologi pendidikan menjadi pembuktian dibutuhkannya lulusan di lembaga bidang jasa $e$ Learning, meskipun dengan fokus lembaga yang berbeda-beda. Adapun sebagai bekal tambahan lulusan yang diharapkan oleh sampel sebagai alumni adalah peningkatan kompetensi adaptivitas diri serta kompetensi baru seperti copywriting yang dikaitkan dengan konten pendidikan dan pelatihan.

\section{SIMPULAN}

Berdasarkan hasil penelitian dapat disimpulkan bahwa pada realitasnya lulusan teknologi pendidikan memang dibutuhkan pada lembaga bidang jasa e-Learning, baik itu dari posibilitas diterimanya lulusan berdasarkan kriteria yang diinginkan lembaga maupun linearitas pekerjaan yang diperoleh alumni teknologi pendidikan. Akan tetapi tidak terbatas kepada pekerjaan yang seputar pengembang platform e-Learning saja melainkan juga ke dalam bagian kontennya (desainer pembelajaran, kurikulum, dan pelatihan, penjamin mutu dan produser media pembelajaran) ataupun proses bisnisnya (pemasaran dan manajemen SDM). Adapun kompetensi yang perlu dikembangkan mahasiswa teknologi pendidikan yang belum terakomodasi oleh kurikulum prodi dari segi soft-skills yaitu adaptivitas diri dan copywriting konten pendidikan dan pelatihan. 


\section{PERNYATAAN PENULIS}

Penulis menyatakan bahwa artikel ini belum pernah diterbitkan dalam jurnal manapun

\section{DAFTAR PUSTAKA}

Adkins, S. S. (2016). The 2016-2021 Worldwide Self-Paced Elearning Market: The Global Elearning Market Is In Steep Decline. Ambient Insight. Http://Www.Ambientinsight.Com/Resources/Documents/Ambientinsight_The 20162021_Worldwide_Self-Paced Elearning_Market.Pdf

Aisyah, D. N., Mayadewi, C. A., Diva, H., Kozlakidisid, Z., Siswanto, S., \& Adisasmito, W. (2020). A Spatial-Temporal Description Of The Sars- Cov-2 Infections In Indonesia During The First Six Months Of Outbreak. Plos One, 15(12), 1-14. Https://Doi.Org/10.1371/Journal.Pone.0243703

Ali, M. (2014). Memahami Riset Perilaku Dan Sosial. Pt Bumi Aksara.

Ariani, D. (2017). Aktualisasi Profesi Teknologi Pendidikan Di Indonesia. Indonesian Journal Of Curriculum And Educational Technology Studies, 5(1), 1-9. Https://Doi.Org/10.15294/Ijcets.V5i1.14244

Dewi, L. (2020). Kurikulum Tahun 2018 Program Studi Teknologi Pendidikan Program Sarjana (S-1). Fakultas Ilmu Pendidikan Universitas Pendidikan Indonesia.

Emmanuel, G., \& Kusumawardani, S. S. (2020). Pengembangan Model Proses Bisnis Elisa Dalam Pencapaian Tujuan Pembelajaran Universitas. Jurnal Teknik Informatika Dan Sistem Informasi, 7(1), 42-55. Http://Eprints.Ukmc.Ac.Id/3582/

Huang, R., Spector, J. M., \& Yang, J. (2019). Educational Technology: A Primer For The 21 st Century. Springer Nature Singapore. Https://Doi.Org/Https://Doi.Org/10.1007/978981-13-6643-7

Irwandi, I. (2020). Implementing Eclectic Method for ELT through Distance Learning during the Covid-19 Pandemic. Educatio, 15(2), 91-103.

Kania, R., Hadi, N., \& Susanti, D. K. (2021). Penerapan Media Pembelajaran Online Melalui Pemanfaatan Google Classroom Saat Pandemi Covid-19 Pada Pelajaran Biologi. Sintesa: Jurnal Ilmu Pendidikan, 16(1), 1-6.

Prawiradilaga, D. S. (2016). Mozaik Teknologi Pendidikan: E-Learning (D. S. Prawiradilaga, D. Ariani, \& H. Handoko (Ed.)). Prenadamedia Group.

Rohmadi, M. (2021). Pemanfaatan Exe Learning Sebagai Media Belajar dari Rumah Selama Pandemi Covid-19. Educatio, 16(1), 37-49.

Sari, T. T., \& Cahyono, A. H. (2020). Pengembangan E-Learning Berbasis Android "Fun Math" Sebagai Alternatif Belajar Matematika Di Tengah Pandemi. Jurnal Cendekia: Jurnal Pendidikan Matematika, 4(2), 1283-1298. Https://Doi.Org/10.31004/Cendekia.V4i2.355

Seprina, I., \& Yulianingsih, E. (2021). Pemanfaatan Moodle Dalam Implementasi E-Learning Di Sekolah Kejuruan (Studi Kasus : Smk Bina Jaya Palembang). Jurnal Ilmiah Betrik: $\begin{array}{llll}\text { Besemah Teknologi Informasi Dan } & \text { Komputer, }\end{array}$ Https://Doi.Org/Https://Doi.Org/10.36050/Betrik.V12i2.323

Subkhan, E., Haryono, H., \& Budisantoso, H. T. (2021). Online Learning In The Time Of Covid-19 Crisis : Its Implementation And Challenges. Proceedings Of The 11th Annual International Conference On Industrial Engineering And Operations Management, 
3677-3682. Http://Www.Ieomsociety.Org/Singapore2021/Papers/658.Pdf

Sugiyono, S. (2019). Metode Penelitian Pendidikan (Kuantitatif, Kualitatif, Kombinasi, R\&D, Dan Penelitian Pendidikan) (3 Ed.). Alfabeta, Cv.

Susilawati, E. (2015). Capacity Development As A Quality Improvement Strategy Of Functional Officials Of Instructional Technology. Jurnal Teknodik, 19(1), 195-206. Https://Doi.Org/Http://Dx.Doi.Org/10.32550/Teknodik.V19i2.160

Warsita, B. (2017). The Roles And Challenges Of Instructional Technology Professional Developers In The 21st Century Learning. Kwangsan: Jurnal Teknologi Pendidikan, 5(2), 77-90. Https://Dx.Doi.Org/10.31800/Jtp.Kw.V5n2.P77--90

Warsita, B. (2020). Product Challenges And Opportunities Of Instructional Designer In Digital Era. Jurnal Teknodik, 24(2), 161-174.

Zulfiati, H. M., Djufri, E., \& Ardhian, T. (2021). Pengembangan E-Learning Schoology Pada Masa Pandemi Covid-19 Di Pgsd Fkip Universitas Sarjanawiyata Tamansiswa. Taman Cendekia: Jurnal Pendidikan Ke-Sd-An, 5(1), 579-592. 